\title{
Update on the molecular profile of the MDA-MB-453 cell line as a model for apocrine breast carcinoma studies
}

\author{
SEMIR VRANIC ${ }^{1,2}$, ZORAN GATALICA $^{1}$ and ZHAO-YI WANG $^{1,3}$ \\ ${ }^{1}$ Department of Pathology, Creighton University Medical Center, Omaha, NE, USA; \\ ${ }^{2}$ Department of Pathology, Clinical Center of the University of Sarajevo, Sarajevo, Bosnia and Herzegovina; \\ ${ }^{3}$ Department of Medical Microbiology and Immunology, Creighton University School of Medicine, Omaha, NE, USA
}

Received March 30, 2011; Accepted July 27, 2011

DOI: $10.3892 / \mathrm{ol} .2011 .375$

\begin{abstract}
Apocrine carcinoma of the breast has recently been refined through gene expression profiling. Due to various pathological studies, we compared the results with the MDA-MB-453 breast cancer cell line, a proposed model for apocrine breast carcinoma. The MDA-MB-453 cell line is androgen receptor-positive and 'triple-negative' in respect to estrogen receptor- $\alpha$, progesterone receptor and the Her-2/ neu protein expression. Cytogenetic analysis of the cell line revealed a hypertriploid clone characterized by extensive numerical and structural abnormalities including loss of the 9p.21 locus (P16-INK4a gene), also evidenced by the lack of $16^{\mathrm{INK} 4 \mathrm{~A}}$ protein expression in Western blot analysis and immunocytochemistry assays. Gains of chromosomes 7 and 17 without underlying EGFR, HER-2/neu, and TOP2A gene amplification were also observed. A mutation in the $K-R A S$ gene (Gly13Asp GGC>GAC) was identified in the cell line, which was not observed in the six patient samples of apocrine breast carcinomas examined. Similarly, constitutive activation of the MAPK/ERK signaling pathway and deregulation of cell cycle proteins (p16-/pRb-/cyclin D1+ phenotype) with exceedingly high proliferation observed in the MDA-MB-453 cell line were not found in the tissue samples. In conclusion, the MDA-MB-453 cell line shares certain features with apocrine breast carcinoma but differs from patient tissues with regard to various significant characteristics, limiting the value of this cell line as a model for human apocrine breast carcinoma investigations. In contrast to the cell line, EGFR-positive apocrine carcinomas do not harbor $K-R A S$ gene mutations, rendering these tumors amenable to targeted therapy with EGFR inhibitors.
\end{abstract}

Correspondence to: Dr Semir Vranic, Department of Pathology, Clinical Center of the University of Sarajevo, Bolnička 25, Sarajevo BA-71000, Bosnia and Herzegovina

E-mail: semir.vranic@gmail.com

Key words: apocrine breast carcinoma, apocrine cell line, MDA-MB-453, androgen receptor

\section{Introduction}

Breast cancer is the most commonly occurring malignancy in women worldwide. Various histological and molecular subtypes of breast cancer have been identified with different biologic implications (1-3). Apocrine differentiation (metaplasia) is frequently observed in the mammary epithelium; however, invasive apocrine carcinomas are rare, constituting less than $5 \%$ of all breast carcinomas $(1,4)$. Apocrine lesions of the breast are characterized by over-expression of the androgen receptor (AR) along with loss of estrogen receptor- $\alpha$ (ER- $\alpha$ ) and the progesterone receptor (PR) (5-7). Molecular studies of invasive apocrine breast carcinoma have shown a specific molecular apocrine profile based on the AR expression that divides ER-negative breast carcinomas into two different clusters: ER-/AR- (basal) and ER-/AR+ (molecular apocrine cluster) (8).

Breast cancer cell lines are widely used for experimental research as models of various subtypes of breast carcinomas (9-12). The MDA-MB-453 breast cancer cell line, obtained from a malignant pleural effusion of a 48-year-old female, has been suggested as a model for the molecular apocrine breast subtype (13-15). The cell line exhibits a characteristic apocrine carcinoma steroid receptor profile: ER- $\alpha$-negative, PR-negative, and AR-positive $(8,13)$. Increased proliferation in response to androgens is the key feature of the cell line, which can be blocked by anti-androgens, such as flutamide $(13,16,17)$. Her-2/neu activity has been well documented in this cell line, as well as the existence of a functional cross-talk between AR and Her-2/neu, involving the MAPK/ERK1/2 pathway $(13,14)$. These features also tend to characterize a substantial proportion of invasive apocrine carcinomas of the breast (18-20).

The aim of the present study was to further characterize the MDA-MB-453 cell line and to correlate it with the results obtained from the apocrine breast carcinoma samples of patients.

\section{Materials and methods}

Breast cancer cell lines and treatment. Human breast cancer cell line MDA-MB-453 was obtained from the American Type Culture Collection (ATCC, Manassas, VA, USA) and used for analysis and experiments, while MDA-MB-231, MCF-7 
Table I. List of the antibodies used in the study.

\begin{tabular}{|c|c|}
\hline Antibody & Manufacturer \\
\hline $\begin{array}{l}\text { ER- } \alpha \text { (clone } 6 \mathrm{~F} 11), \mathrm{PR} \text { (clone } 16), \\
\text { Her-2/neu (Clone CB11), cyclin D1 }\end{array}$ & Ventana Medical Systems \\
\hline $\begin{array}{l}\text { EGFR, MAPK1/2 (ERK1/2), } \\
\text { pERK1/2 (Thr202/Tyr204) }\end{array}$ & Cell Signaling Technology \\
\hline p16 (mouse monoclonal IgG1к) & Cell Marque \\
\hline 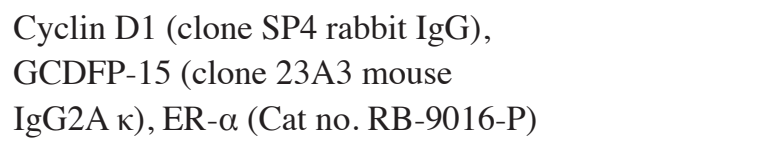 & Neomarkers \\
\hline $\begin{array}{l}\text { EGFR (PharmDX diagnostic kit), } \\
\text { Topoisomerase-II } \alpha \text { (Clone Ki-S1), } \\
\text { Cytokeratin 5/6 (D5/16B4), p63 (clone 4A4) }\end{array}$ & DakoCytomation \\
\hline $\begin{array}{l}\text { Rb (IF8): sc-102, pRb(Ser795), } \\
\text { p16 (N-20: sc-467), p53 (DO-1): sc-126, } \\
\text { Actin [(I-19): sc-1616], AR (clone AR441: sc-7305), } \\
\text { pEGFR (Tyr845), Her-2 (Neu (CB11): sc-52349), } \\
\text { p-Neu (Tyr 1248)-R: sc-12352-R }\end{array}$ & Santa Cruz Biotechnology \\
\hline
\end{tabular}

and BT-474 cell lines from the ATCC served as controls. MDA-MB-453, MDA-MB-231 and BT-474 were cultured in Dulbecco's modified Eagle's medium (DMEM, Gibco-BRL, Invitrogen, Carlsbad, CA, USA) supplemented with $10 \%$ fetal bovine serum (FBS) at $37^{\circ} \mathrm{C}$ in a humidified $\mathrm{CO}_{2}$ incubator. The MCF-7 cell line was cultured in Improved modified Eagle's medium (IMEM, Invitrogen) supplemented with $10 \%$ FBS. Prior to the experiments, the cells were cultured in phenol-red-free DMEM (Invitrogen) for $24 \mathrm{~h}$, and then in serum-free DMEM overnight. U0126 (MEK1/2 inhibitor, Cell Signaling Technology, Danvers, MA, USA), a highly selective inhibitor of MEK1/2, was used.

Breast tissue samples. Formalin-fixed paraffin-embedded blocks of 8 cases of apocrine carcinoma (seven invasive and one in situ case) that corresponded to the cell line profile (ER- $\alpha-$, PR-, AR+ and Her-2/neu -/+) were selected from the previously well-characterized cohort (18) and used for comparative analysis.

Protein expression analysis. Protein expression was analyzed by Western blot analysis in cell lysates or by immunocytochemistry (ICC) and immunohistochemistry (IHC) on formalin-fixed and paraffin-embedded cell blocks prepared from the MDA-MB-453 cell line and tissue blocks from breast tissue samples (the list of antibodies is shown in Table I). For ICC and IHC analysis, commercially available detection kits and automated staining procedures were employed (18). Cell lysates, immunoprecipitations and Western blot analysis were carried out using standard procedures as previously described $(21,22)$. Signals were detected by enhanced chemiluminiscence (ECL; Amersham, GE Healthcare Biosciences, Pittsburgh, PA, USA).

A positive $\mathrm{p} 16^{\mathrm{INK} 4 \mathrm{~A}}$ expression was defined as the presence of nuclear and/or cytoplasmic staining, and the percentage of positive cells was recorded $(23,24)$. For ER- $\alpha$, PR, AR, cyclin D1, p53, p63 and topoisomerase-II $\alpha$ expression, only nuclear labeling was scored $(24,25)$. For Her-2/neu and EGFR proteins, only membranous staining was considered positive. The scoring was carried out according to the manufacturer's (EGFR, Dako, Carpinteria, CA, USA) and American Society of Clinical Oncology/College of American Pathologists' guideline recommendations (Her-2/neu protein) (26). GCDFP-15 and CK5/6 proteins were considered positive if any membranous/cytoplasmic staining was observed.

Conventional cytogenetics. G-banding procedures were performed on metaphase cells. Metaphase chromosomes were banded with Wright trypsin and karyotypes were described following the established international guidelines (27).

Fluorescent in situ hybridization (FISH). FISH was performed to evaluate copy numbers at $E G F R, T O P 2 A$ and HER-2/neu loci. Chromosome enumeration probes CEP7 and CEP17 were used as indicators of chromosome copy numbers (Abbott Molecular Inc., Des Plaines, IL, USA). A total of 100 nuclei were scored per sample. A ratio of HER-2/CEP17 $>2.2$ was defined as gene amplification; a ratio of 1.8-2.1 was interpreted as borderline, and a ratio of $<1.8$ was defined as negative. The same criteria were used for the interpretation of EGFR/CEP7 and TOP2A/CEP17 ratios, respectively. For statistical purposes, equivocal FISH results (ratio of 1.8-2.1) were considered negative (27). Polysomy 7 and 17 were defined as $\geq 3$ CEP signals per cell $(18,28)$.

Flow cytometry. Flow cytometry (FC) was applied to measure the S-phase fraction of MDA-MB-453 cells. Cells at 50\% confluence were harvested and $1 \mathrm{ml}$ cold $70 \%$ ethanol was slowly added to the cell pellet while vortexing. Ethanol-fixed cells were treated with $100 \mu \mathrm{g} / \mathrm{ml}$ RNaseA and $50 \mu \mathrm{g} / \mathrm{ml}$ 
Table II. A summary of the key findings in the cell line and apocrine carcinoma tissue samples.

\begin{tabular}{|c|c|c|}
\hline Feature & MDA-MB-453 & Apocrine carcinoma tissue samples \\
\hline Estrogen/progesterone receptor & Negative & Negative $^{b}$ \\
\hline Androgen receptor & Positive $^{a}$ & Positive $^{b}$ \\
\hline GCDFP-15 protein & Negative & Positive $^{c}$ \\
\hline HER-2/neu status & $\begin{array}{l}\text { Low protein } \\
\text { expression }{ }^{\mathrm{a}} / \text { no gene } \\
\text { amplification }\end{array}$ & $\begin{array}{c}\text { High protein } \\
\text { expression common/gene } \\
\text { amplification }^{\mathrm{b}}\end{array}$ \\
\hline EGFR status & $\begin{array}{l}\text { Low protein } \\
\text { expression }{ }^{\mathrm{a}} / \text { no gene } \\
\text { amplification }\end{array}$ & $\begin{array}{c}\text { High protein } \\
\text { expression common/no gene } \\
\text { amplification }^{\mathrm{b}}\end{array}$ \\
\hline$K R A S$ gene status & $\begin{array}{l}\text { Mutated (Gly13Asp } \\
\text { GGC>GAC) }\end{array}$ & Not mutated \\
\hline$B R A F$ gene status & Not mutated & Not mutated \\
\hline pl6 $6^{I N K 4 A}$ protein & $\begin{array}{c}\text { Lost due to gene deletion } \\
\text { at } 9 \mathrm{p} .21 / \text { no protein } \\
\text { detected }\end{array}$ & $\begin{array}{c}\text { Present (variable } \\
\text { cytoplasmic/nuclear } \\
\text { staining) }\end{array}$ \\
\hline Cyclin D1 protein & Highly over-expressed & Low expression \\
\hline Polysomy 7 and 17 (CEP7 and 17) & Present & Frequently observed $^{\mathrm{b}}$ \\
\hline Basal markers (CK5/6, p63) & Low expression & Low expression $^{\mathrm{d}}$ \\
\hline
\end{tabular}

${ }^{\mathrm{a} B y}$ Western blot analysis; ${ }^{\mathrm{b}}$ Vranic et al (18); ${ }^{\mathrm{C}}$ Tavassoli et al (1); ${ }^{\mathrm{d}}$ Weigelt et al (4).

propidium iodide (PI) in PBS at room temperature for $30 \mathrm{~min}$. Flow cytometry of cell cycle distribution was performed using a FACSCalibur flow cytometer (BD-Biosciences, San Jose, CA, USA). The results were analyzed using Multicycle for Windows.

Gene mutation analysis. These assays included the detection of 12 mutations in codons 12 and 13 of the $K-R A S$ gene as well as the V600E mutation in exon 15 of the $B-R A F$ gene. The analysis was performed using a Mutector II assay, using proprietary Shift Termination Assay (STA) technology (TrimGen Corporation, Sparks, MD, USA) following the previously described protocol (29). For quality control of the $K-R A S$ mutation analysis, we used a colon cancer biopsy known to be positive for $K-R A S$ mutation, while a case of malignant melanoma served as a positive control for $B-R A F$ mutation.

Statistical analysis. Quantitative data of the experimental studies were expressed as the mean \pm SD. The student's t-test was used to test the differences between responses in the exposed and control groups. Statistical Package for the Social Sciences version 17.0 (SPSS, Chicago, IL, USA) was used for statistical analysis. $\mathrm{P}<0.05$ was considered to be statistically significant.

\section{Results}

Profiling of MDA-MB-453 cell line. A summary of the key findings and comparison with the apocrine carcinoma tissue samples is shown in Table II. The MDA-MB-453 cell line was negative for ER- $\alpha$, PR and Her-2/neu protein on ICC, whereas AR was found to be positive by Western blot analysis. Notably, the ICC assay demonstrated no nuclear staining but predominantly cytoplasmic distribution of AR, whereas the GCDFP-15 protein was absent. Western blot analysis revealed low levels of Her-2/neu and phosphorylation of the Her-2/neu protein at Tyr1248 in comparison with BT-474 cells, an ER-positive breast cancer cell line with HER-2/ neu gene amplification. Western blot analysis revealed that levels of total EGFR and phosphorylation of EGFR at Tyr845 were lower in MDA-MB-453 cells compared with EGFRover-expressing MDA-MB-231 cells. In contrast, the ICC assay revealed a strong EGFR protein expression (score 3+). FISH analysis revealed neither HER-2/neu (HER2/CEP17 was 3.96/3.68, ratio: 1.08) nor EGFR gene amplification (EGFR/ CEP7 was 3.23/2.90, ratio: 1.11). Gains of chromosomes 7 and 17 (CEP7 and 17) observed with FISH were further confirmed using conventional cytogenetic analysis, which revealed a hypertriploid clone characterized by extensive numerical and structural abnormalities including gains of chromosomes 7 , 11, 17, 19 and 21 and losses of chromosomes X, 3, 4, 9, 13, 14, 16 and 18.

Of particular functional importance was the deletion of the $9 \mathrm{p} 21$ locus that harbors the INK4A gene $\left(\mathrm{p} 16^{\mathrm{INK} 4 \mathrm{~A}}\right)$ and $I N K 4 B$ gene (p15), as evidenced by the loss of the p16 ${ }^{\text {INK4A }}$ protein expression in Western blot or ICC analysis (Fig. 1A).

CK5/6 was completely absent, whereas the p63 protein expression with defined nuclear staining was observed in approximately $10 \%$ of the cells.

MDA-MB-453 cells exhibit a high proliferation rate. MDA-MB-453 cells exhibited an excessive proliferation rate under optimal culture conditions as its S-phase fraction measured up to $70 \%$ by flow cytometry. This rate was consistent with the cyclin D1 over-expression (positive in $\sim 70 \%$ of the cells), inactivation of retinoblastoma protein 


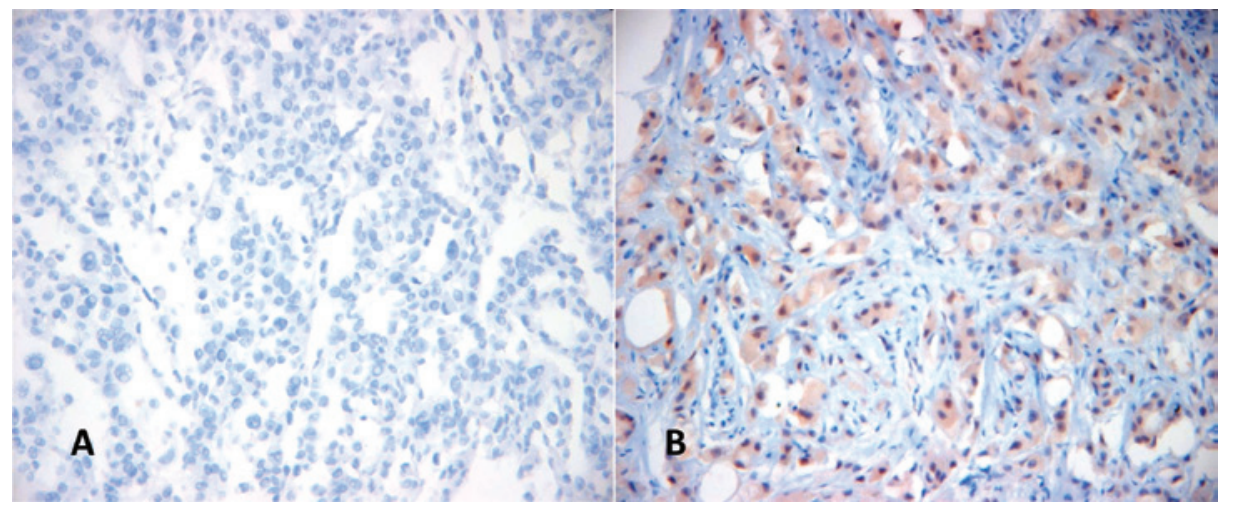

Figure 1. p16 ${ }^{\mathrm{INK} 4 \mathrm{~A}}$ protein was completely absent in MDA-MB-453 cells (A) whereas apocrine carcinoma tissue samples predominantly retained a membranous and cytoplasmic pattern of staining (B).

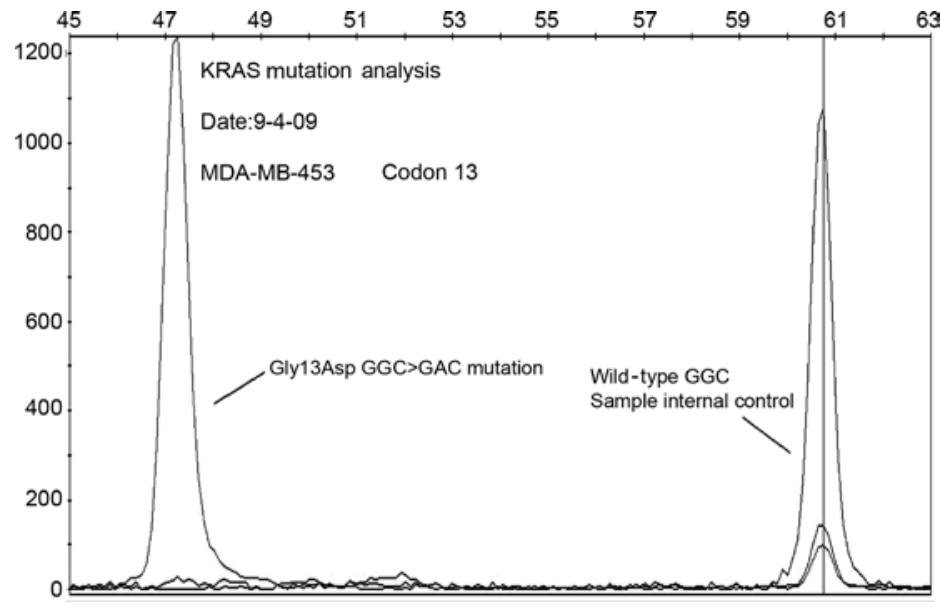

Figure 2. Mutational analysis of the K-RAS gene revealed codon 13 mutation (Gly 13 Asp GGC $>$ GAC), a mutation that constitutively activates K-Ras in the MDA-MB-453 cell line.

(Rb), measured by its phosphorylation at Ser795, and the loss of $16^{\mathrm{INK} 4 \mathrm{~A}}$ protein expression. The cell line also exhibited a high p53 protein expression measured by both Western blot and ICC analysis. Consequently, topoisomerase-II $\alpha$ was also strongly expressed in approximately $70 \%$ of the cells (without underlying TOP $2 A$ gene amplification, TOP2A/CEP17: 2.86/ 2.80, ratio: 1.02). When cultured in a serum-free medium for $24 \mathrm{~h}$, the cell line remained highly proliferative with an S-phase fraction of approximately $40 \%$. The cell line was also capable of sustained proliferation in a serum-free medium for up to $48 \mathrm{~h}$, as demonstrated by the S-phase fraction.

MDA-MB-453 cells harbor a K-RAS mutation and exhibit constitutive activation of the MAPK/ERK pathway. Mutational analysis of the $K-R A S$ gene revealed codon 13 mutation (Gly 13 Asp GGC>GAC), a mutation that constitutively activates $\mathrm{K}-\mathrm{Ras}$ in the MDA-MB-453 cell line (Fig. 2), whereas there is no gene alteration in the $B-R A F$ gene. Western blot analysis confirmed that ERK1/2 is highly phosphorylated in cells irrespective of the concentration of the fetal calf serum, and culture conditions. In addition, MDA-MB-453 retained high ERK activity even after $48 \mathrm{~h}$ in serum-free medium, and was highly sensitive to the specific MEK1/2 inhibitor U0126. Low concentrations of U0126 $(0.1 \mu \mathrm{M})$ led to a partial inhibi- tion of ERK1/2 phosphorylation after $12 \mathrm{~h}$. The exposure of MDA-MB-453 cells to U0126 at a concentration of $10 \mu \mathrm{M}$ for various time periods (from $15 \mathrm{~min}$ to $24 \mathrm{~h}$ ) led to a markedly reduced S-phase fraction as measured by flow cytometry (Fig. 3A and B). Thus, $12 \mathrm{~h}$ treatment of the MDA-MB-453 cells with U0126 resulted in a significantly reduced proliferation rate in the experimental group in comparison with the control group (22.6 vs. $38.3 \%$, reduction $\sim 42 \%, \mathrm{p}<0.001$, Student's t-test). Western blot analysis with phospho-specific anti-ERK1/2 antibody also showed that U0126 abolished ERK1/2 phosphorylation in MDA-MB-453 cells.

Breast tissue sample analysis. Of 5 tested patient samples of the apocrine carcinomas, 1 exhibited an absence of p16 ${ }^{\text {INK4A }}$ protein expression, 3 samples (two invasive and one in situ carcinoma) had predominantly cytoplasmic $\mathrm{p} 16^{\mathrm{INK} 4 \mathrm{~A}}$ expression (observed in $20-80 \%$ of the tumor cells), whereas only 1 case retained a nuclear p16 ${ }^{\mathrm{INK} 4 \mathrm{~A}}$ expression intensity, compared with the positive control (Fig. 1B). Cyclin D1 expression was observed in 3 out of 5 cases. However, only 2 of these cases reached more than $10 \%$ of the positive cells with predominantly weak to moderate nuclear intensity.

$K-R A S$ and $B-R A F$ mutational analysis performed on 6 invasive apocrine carcinoma samples showed no gene altera- 
A

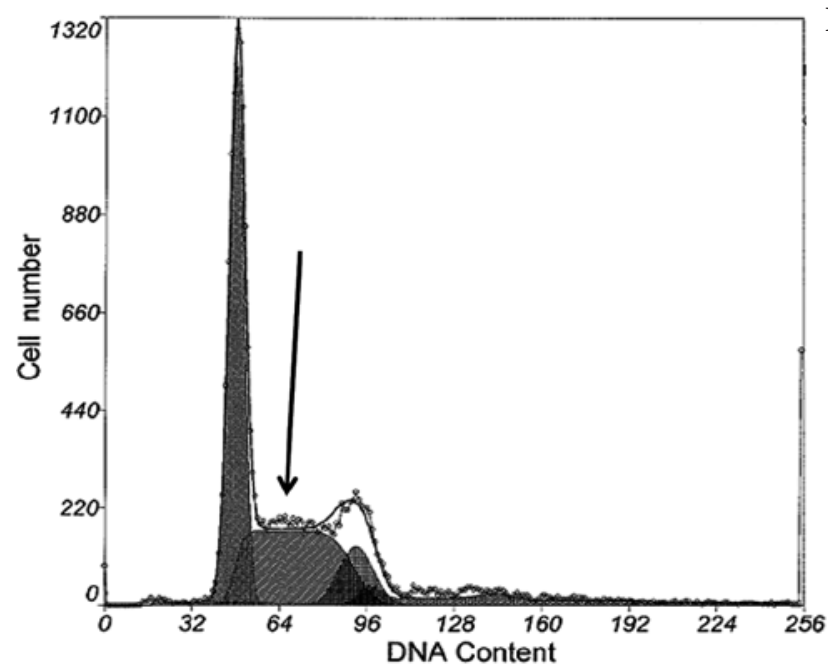

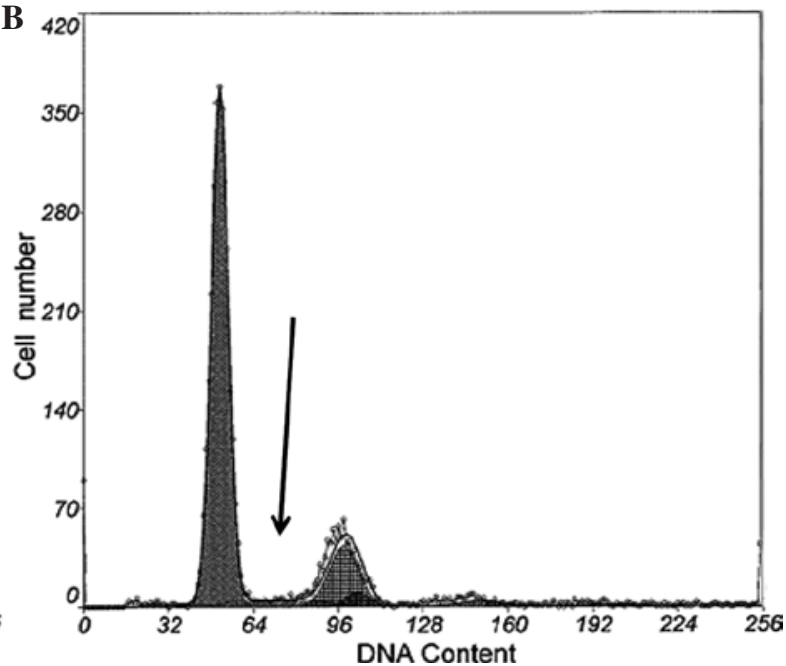

Figure 3. The exposure of MDA-MB-453 cells to U0126 at a concentration of $10 \mu \mathrm{M}$ at different time periods (from 15 min to 24 h) led to a dramatically reduced S-phase fraction in the cells as measured by flow cytometry. Black arrows indicate S-phase fraction after $24 \mathrm{~h}$ in control group (A) where S-phase was $\sim 39 \%$, and exposed group (B) where S-phase was $\sim 6 \%$.

tions in any of the studied cases. Notably, these cases had a strong EGFR protein over-expression on IHC (scores $2+/ 3+$ on IHC) without underlying EGFR gene amplification (18).

\section{Discussion}

The present study describes complex and multiple cytogenetic and molecular alterations in the MDA-MB-453 cell line that is currently considered to be a model for breast apocrine carcinoma. Conventional cytogenetic analysis revealed that MDA-MB-453 is a hypertriploid cell line that corresponds closely to its metastatic origin and high malignant potential (10). We also observed considerable discrepancies between published cytogenetic findings regarding the cell line and our own results, although certain previously reported cytogenetic findings, including gains of chromosomes 7 and 17 and loss of the 9p.21 locus (CDKN2 gene) (30), are also observed in our study. Thus, previous studies $(31,32)$ reported HER-2/neu gene amplification in the MDA-MB-453 cell line, whereas our analysis did not support those findings. FISH and conventional cytogenetic analysis revealed a gain (polysomy) of CEP17 in only a small population of cells ( $\sim 5 \%$ of the counted cells) that carried HER-2/neu gene amplification. Levels of total Her-2/ neu expression and phosphorylation of Her-2/neu at Tyr1248, often associated with HER-2/neu gene amplification (33), were lower in comparison with the positive cell control (BT-474 cell line). Belsches-Jablonski et al (34) also revealed a low Her-2/neu protein expression in the MDA-MB-453 cell line, whereas Kao et al (11) found low copy numbers of the HER-2/ neu gene in the cell line using a quantitative polymerase chain reaction, and thus classified MDA-MB-453 cells as an HER-2negative cell line. Consequently, the classification of the cell line varies from luminal $(12,31,32)$ or 'weakly luminal' (10) to an apocrine cell line model $(8,13-15)$. We propose that the observed disparities are caused by the prolonged cell culture, which may modify genetic/phenotypic properties of the cell line $(9,10)$, and further stress the importance of a laboratory self validation of the cell line.
Our study reports for the first time a codon 13 mutation in the $K-R A S$ gene followed by constitutive MAPK/ERK activation in the MDA-MB-453 cell line $(35,36)$. The $K-R A S$ gene is an integral part of the MAPK signaling pathway, whose activation strongly correlates with the degree of the $K-R A S$ gene activation (36). The MAPK/ERK signaling pathway is crucial in the regulation of cell proliferation, differentiation, survival and metastasis through ultrasensitive switch-like responses to various stimuli depending on the strength and duration of stimulation (35,37-40). Some of these effects, such as prolife-ration, may be abolished by the targeted inhibition, as we demonstrated using the specific MEK1/2 inhibitor U0126 in our study.

$K-R A S$ gene mutations (usually restricted to codons 12 , 13 and 61) are frequently observed in human tumors $(\sim 15 \%)$ (41) and established breast cancer cell lines (35). However, Hollestelle et al (35) reported PTEN but not K-RAS gene mutation in this cell line, although these authors found that $13 \%$ of the studied breast cancer cell lines harbored $K-R A S$ gene mutations. Furthermore, results obtained from the cell line were not in concordance with the data from the breast cancer samples, which is consistent with findings of previous reports that have confirmed the lack of $K-R A S$ mutations in breast carcinomas $(36,42-45)$. Notably, the lack of $K-R A S$ mutations in apocrine carcinomas may become a potential therapeutic benefit, since the tested cases were EGFR-positive and thus are potentially amenable to targeted anti-EGFR therapy (44). $B-R A F$ gene mutations, mainly involving the V600E locus, have also been described in a wide range of human tumors with the highest frequency in malignant melanoma (41). These mutations are rarely observed in breast carcinoma (41). Neither the cell line nor apocrine breast carcinoma samples harbored the $B-R A F$ gene mutations.

Another significant finding in this study was the deletion of the 9p21-22 region, responsible for the complete loss of the $16^{\mathrm{INK} 4 \mathrm{~A}}$ protein as confirmed by ICC and Western blot analysis. This finding is consistent with a recent study that reported an allelic loss at 9p21 loci in MDA-MB-453 cells with a barely detectable p16 ${ }^{\mathrm{INK} 4 \mathrm{~A}}$ protein expression (29). 
p16 $6^{\mathrm{INK} 4 \mathrm{~A}}$, the product of the $C D K N 2$ gene, one of the key cell cycle regulators, inhibits phosphorylation of the retinoblastoma protein, and thus acts as a negative regulator of the cell cycle (46). In contrast, loss of p16 $6^{\mathrm{INK} 4 \mathrm{~A}}$ was found in only 1 of 5 tested apocrine carcinomas of the breast with loss $\mathrm{p} 16^{\mathrm{INK} 4 \mathrm{~A}}$ protein expression, whereas the remaining 4 exhibited predominantly cytoplasmic patterns of distribution of the p16 ${ }^{\mathrm{INK} 4 \mathrm{~A}}$ protein. Notably, several investigators previously reported a cytoplasmic distribution of the $\mathrm{p} 16^{\mathrm{INK} 4 \mathrm{~A}}$ protein in a subset of breast carcinomas $(47,48)$, which correlated with a high histological grade, loss of ER and PR, p53 protein over-expression and accelerated tumor proliferation, the parameters frequently featured in apocrine carcinoma and the MDA-MB-453 cell line. Similarly, the cell line exhibited a high cyclin D1 expression, which was not observed in the breast tissue samples.

In conclusion, the observed cytogenetic and molecular alterations in the MDA-MB-453 cell line were not consistently present in the apocrine tumor samples. Our cell culture results also differ in certain respects from previously published data. MDA-MB-453 is not an ideal model of apocrine carcinomas as recently defined using molecular methods. Notably, EGFRpositive apocrine carcinomas of the breast do not tend to harbor $K-R A S$ gene mutations observed in the cell line, which indicates that targeted therapy with EGFR inhibitors may be a viable alternative in some patients.

\section{Acknowledgements}

This study was supported by the National Institutes of Health Grant, DK070016 (Z.-Y. Wang). Dr Semir Vranic was a research fellow at Creighton University Medical Center, Omaha, NE, USA, and was supported by a UICC American Cancer Society Beginning Investigators Fellowship (ACSBI) (ACS/08/004) funded by the American Cancer Society. We appreciate the technical assistance of Kay Krogman, Deborah Jankovich, and Kristin Bonnstetter (Creighton Medical Laboratories, Creighton University School of Medicine, Omaha, NE, USA) and Dr Faruk Skenderi (Sarajevo University School of Medicine, Bosnia and Herzegovina). We are also indebted to Dr Warren Sanger and Ms. Marilu Nelson (The University of Nebraska Medical Center, Omaha, NE) for their excellent cytogenetics support.

\section{References}

1. Tavassoli FA and Devilee P (eds.): World Health Organization Classification of tumours. Pathology and genetics of tumours of the breast and female genital organs. IARC Press: Lyon 2003.

2. Perou CM, Sørlie T, Eisen MB, et al: Molecular portraits of human breast tumours. Nature 406: 747-752, 2000.

3. Sørlie T, Perou CM, Tibshirani R, et al: Gene expression patterns of breast carcinomas distinguish tumor subclasses with clinical implications. Proc Natl Acad Sci USA 98: 10869-10874, 2001.

4. Weigelt B, Horlings HM, Kreike B, et al: Refinement of breast cancer classification by molecular characterization of histological special types. J Pathol 216: 141-150, 2008.

5. Gatalica Z: Immunohistochemical analysis of apocrine breast lesions. Consistent over-expression of androgen receptor accompanied by the loss of estrogen and progesterone receptors in apocrine metaplasia and apocrine carcinoma in situ. Pathol Res Pract 193: 753-758, 1997.

6. Tavassoli FA, Purcell CA, Bratthauer GL, et al: Androgen receptor expression along with loss of bcl-2, ER, and PR expression in benign and malignant apocrine lesions of the breast: implications for therapy. Breast J 2: 261-269, 1996.
7. Bratthauer GL, Lininger RA, Man YH and Tavassoli FA: Androgen and estrogen receptor mRNA status in apocrine carcinomas. Diagn Mol Pathol 11: 113-118, 2002.

8. Farmer $\mathrm{P}$, Bonnefoi $\mathrm{H}$, Becette $\mathrm{V}$, et al: Identification of molecular apocrine breast tumours by microarray analysis. Oncogene 24: 4660-4671, 2005.

9. Burdall SE, Hanby AM, Lansdown MRJ and Speirs V: Breast cancer cell lines: friend or foe? Breast Cancer Res 5: 89-95, 2003.

10. Lacroix M and Leclercq G: Relevance of breast cancer cell lines as models for breast tumours: an update. Breast Cancer Res Treat 83: 249-289, 2004.

11. Kao J, Salari K, Bocanegra M, et al: Molecular profiling of breast cancer cell lines defines relevant tumor models and provides a resource for cancer gene discovery. PLoS One 4: e6146, 2009.

12. Neve RM, Chin K, Fridlyand J, et al: A collection of breast cancer cell lines for the study of functionally distinct cancer subtypes. Cancer Cell 10: 515-27, 2006.

13. Naderi A and Hughes-Davies L: A functionally significant crosstalk between androgen receptor and erbB 2 pathways in estrogen receptor negative breast cancer. Neoplasia 10: 542-548, 2008.

14. Chia KM, Liu J, Francis GD and Naderi A: A feedback loop between androgen receptor and ERK signaling in estrogen receptor-negative breast cancer. Neoplasma 13: 154-66, 2011.

15. De Longueville F, Lacroix M, Barbuto AM, et al: Molecular characterization of breast cancer cell lines by a low-density microarray. Int J Oncol 27: 881-892, 2005.

16. Doane AS, Danso M, Lal P, et al: An estrogen receptor-negative breast cancer subset characterized by a hormonally regulated transcriptional program and response to androgen. Oncogene 25: 3994-4008, 2006.

17. Hall RE, Birrell SN, Tilley WD and Sutherland RL: MDA-MB-453, an androgen-responsive human breast carcinoma cell line with high level androgen receptor expression. Eur J Cancer 30A: 484-490, 1994.

18. Vranic S, Tawfik O, Palazzo J, et al: EGFR and HER-2/neu expression in invasive apocrine carcinoma of the breast. Mod Pathol 23: 644-653, 2010.

19. Bhargava R, Beriwal S, Striebel JM and Dabbs DJ: Breast cancer molecular class ERBB2: preponderance of tumors with apocrine differentiation and expression of basal phenotype markers CK5, CK5/6, and EGFR. Appl Immunohistochem Mol Morphol 18: $113-118,2010$.

20. Varga Z, Zhao J, Ohlschlegel C, Odermatt B and Heitz PU: Preferential HER-2/neu overexpression and/or amplification in aggressive histological subtypes of invasive breast cancer. Histopathology 44: 332-338, 2004.

21. Zhang XT, Kang LG, Ding L, Vranic S, Gatalica Z and Wang ZY: A positive feedback loop of ER- $\alpha 36 /$ EGFR promotes malignant growth of ER-negative breast cancer cells. Oncogene 30: 770-780, 2011.

22. Wang Z, Zhang X, Shen P, Loggie BW, Chang Y and Deuel TF: A variant of estrogen receptor-\{alpha\}, hER-\{alpha\}36: transduction of estrogen- and antiestrogen-dependent membrane-initiated mitogenic signaling. Proc Natl Acad Sci USA 103: 9063-9068, 2006.

23. Subhawong AP, Subhawong T, Nassar H, et al: Most basal-like breast carcinomas demonstrate the same Rb-/p16+ immunophenotype as the HPV-related poorly differentiated squamous cell carcinomas which they resemble morphologically. Am J Surg Pathol 33: 163-75, 2009.

24. Milde-Langosch K, Bamberger AM, Rieck G, Kelp B and Löning T: Overexpression of the p16 cell cycle inhibitor in breast cancer is associated with a more malignant phenotype. Breast Cancer Res Treat 67: 61-70, 2001

25. Elayat G, Selim AG and Wells CA: Alterations of the cell cycle regulators cyclin $\mathrm{D} 1$, cyclin $\mathrm{A}, \mathrm{p} 27, \mathrm{p} 21, \mathrm{p} 16$, and pRb in apocrine metaplasia of the breast. Breast J 15: 475-482, 2009.

26. Wolff AC, Hammond ME, Schwartz JN, et al: American Society of Clinical Oncology/College of American Pathologists guideline recommendations for human epidermal growth factor receptor 2 testing in breast cancer. J Clin Oncol 25: 118-145, 2007.

27. Shaffer LG and Tommerup N (eds.): ISCN 2005. An International System for Human Cytogenetic Nomenclature. Karger, Basel, 2005.

28. Vranic S, Teruya B, Repertinger S, Ulmer P, Hagenkord J and Gatalica Z: Assessment of HER2 gene status in breast carcinomas with polysomy of chromosome 17. Cancer 117: 48-53, 2011.

29. Shackelford W, Deng S, Murayama K and Wang J: A new technology for mutation detection. Ann N Y Acad Sci 1022: 257-262, 2004. 
30. Hollestelle A, Nagel JH, Smid M, et al: Distinct gene mutation profiles among luminal-type and basal-type breast cancer cell lines. Breast Cancer Res Treat 121: 53-64, 2010.

31. Arriola E, Marchio C, Tan DS, et al: Genomic analysis of the HER 2/TOP2A amplicon in breast cancer and breast cancer cell lines. Lab Invest 88: 491-503, 2008.

32. Mackay A, Tamber N, Fenwick K, et al: A high-resolution integrated analysis of genetic and expression profiles of breast cancer cell lines. Breast Cancer Res Treat 118: 481-498, 2009.

33. Taniyama K, Ishida K, Toda T, et al: Tyrosine1248-phosphorylated HER2 expression and HER2 gene amplification in female invasive ductal carcinomas. Breast Cancer 15: 231-240, 2008.

34. Belsches-Jablonski AP, Biscardi JS, Peavy DR, Tice DA, Romney DA and Parsons SJ: Src family kinases and HER2 interactions in human breast cancer cell growth and survival. Oncogene 20: 1465-1475, 2001.

35. Hollestelle A, Elstrodt F, Nagel JHA, Kallemeijn WW and Schutte M: Phosphatidylinositol-3-OH kinase or RAS pathway mutations in human breast cancer cell lines. Mol Cancer Ther 5: 195-201, 2007

36. Von Lintig FC, Dreilinger AD, Varki NM, Wallace AM, Casteel DE and Boss GR: Ras activation in human breast cancer. Breast Cancer Res Treat 62: 51-62, 2000.

37. Torii S, Yamamoto T, Tsuchiya Y and Nishida E: ERK MAP kinase in G1 cell cycle progression and cancer. Cancer Sci 97: 697-702, 2006.

38. $\mathrm{Lu} \mathrm{Z}$ and $\mathrm{Xu}$ S: ERK1/2 MAP kinases in cell survival and apoptosis. IUBMB Life 58: 621-631, 2006.

39. Roberts PJ and Der CJ: Targeting the Raf-MEK-ERK mitogenactivated protein kinase cascade for the treatment of cancer. Oncogene 26: 3291-3310, 2007.
40. McCubrey JA, Steelman LS, Chappell WH, et al: Role of the $\mathrm{RAF} / \mathrm{MEK} / \mathrm{ERK}$ pathway in cell growth, malignant transformation and drug resistance. Biochim Biophysic Acta 1773: 1263-1284, 2007.

41. Davies H, Bignell GR, Cox C, et al: Mutations of the BRAF gene in human cancer. Nature 417: 949-954, 2002.

42. Capela G, Cronauer-Mitra S, Peinado MA and Perucho M: Frequency and spectrum of mutations at codons 12 and 13 of the C-K-Ras gene in human tumors. Environ Health Perspect 93: 125-131, 1991.

43. Myakis S, Sourvinos G and Spandidos DA: Differential expression and mutation of the ras family genes in human breast cancer. Biochem Biophys Res Commun 251: 609-612, 1998.

44. Sánchez-Muñoz A, Gallego E, de Luque V, et al: Lack of evidence for KRAS oncogenic mutations in triple-negative breast cancer. BMC Cancer 10: 136, 2010.

45. Karnoub AE and Weinberg RA: Ras oncogenes: split personalities. Nat Rev Mol Cell Biol 9: 517-531, 2008.

46. Geradts J and Wilson PA: High frequency of aberrant p16(INK4A) expression in human breast cancer. Am J Pathol 149: 15-20, 1996.

47. Emig R, Magener A, Ehemann V, et al: Aberrant cytoplasmic expression of the p16 protein in breast cancer is associated with accelerated tumour proliferation. Br J Cancer 78: 1661-1668, 1998.

48. Di Vinci A, Perdelli L, Banelli B, et al: p16INK4a promoter methylation and protein expression in breast fibroadenoma and carcinoma. Int J Cancer 114: 414-421, 2005. 